\title{
Directive Speech Acts in Different Social Classes
}

\author{
Dwi Indarti
}

Universitas Bina Sarana Informatika

e-mail: dwi.diw@bsi.ac.id

\author{
Cara Sitasi: \\ Indarti, D. (2019). Directive Speech Acts in Different Social Classes. Wanastra, 11(2), 121-126.
}

\begin{abstract}
This paper tries to investigate the use of directive speech acts in different social class. Using the six types of directive speech acts proposed by Ervin-Tripp (1976), they are need statement, imperative, imbedded imperative, permission directive, question directive and hint. This paper focuses on the main male characters' utterances from two novels; Crazy Rich Asians written by Kevin Kwan which represents upper class society and I am the Messenger written by Markus Zusak which represents lower class society. The results show that both upper and lower social classes mostly use imperative directive (42 utterances or 80\%). Lower class male character uses more 'need statement directive' than upper class male character. Meanwhile, upper class character uses more 'question directive' than lower class character. Generally, upper class people use the directive as commands to their employees while the lower class character uses directive in his work as a cab driver which required him to be more direct in asking and offering the customers.
\end{abstract}

Keywords: Speech Act, Directives, Novels: Social Class.

\section{INTRODUCTION}

Linguistic feature is a constellation of lexical and grammatical structures which characterize particular uses of language (Martin, 1992 as cited in Matiini, 2015, p.16). Lee (2006) defines linguistic features as a lexical choice which covers condensed words and vernacular or colloquial language as well as syntactic structure and semantic representation. Further, Corbett (2006, p. 193) explicitly suggests that "when attempting to model and to understand the complexity of natural language, linguists typically have recourse to features".

Mulac et al (2001, p. 125) classify the linguistic features into sixteen types: (1) References to quantity, (2) Judgmental adjectives, (3) Elliptical sentences, (4) Directives, (5) Locatives, (6) 'I' references, (7) Intensive adverbs, (8) References to emotion, (9) Dependent clauses, (10) Sentence initial adverbials, (11) Mean length sentence, (12) Unvertainly verbs, (13) Oppositions, (14) Negations, (15) Hedges and (16) Questions.

Meanwhile speech acts are the types of acts performed by a speaker in uttering a sentence. Austin (1962:12) stated that speech act is best defined as "in saying something, we do something". Speech act concerns how an act is performed by means of language. Speech act is best defined as "in saying something, we do something" (Austin, 1962, p. 12).
Further more, Austin (as cited in Leech, 1996, p. 199) distinguishes three kinds of action within utterances:

1. Locutionary act is the act of uttering a sentence with a certain meaning. Renkema (1993, p. 22) states that locutionary act is the physical act of producing an utterance.

2. Illocutionary act is the act performed in saying the locution. It contains the intention of the speaker when saying something.

3. Perlocutionary act is the effect of illocutionary act, on the particular occasion of use, has on the hearer

Speech Acts theory has been proposed by Searle (1969) who categorizes speech acts into five:

a) Directives. It is an attempt by speaker to get hearer to do something. The examples of directives are asking, begging, commanding, ordering, requesting, and so on.

b) Commisives. Speaker commits himself or herself to the performance of an action. The examples of commisives are offering, promising, swearing, threatening, vowing.

c) Assertives. Speaker represents a state of affairs. The utterances may be judged true or false because they aim to describe a state of affairs in the world, for example 
affirming, reporting, informing, stating, and so on.

d) Expressives. Speaker expresses a psychological state about the situation. The examples are welcoming, congratulating, thanking, etc.

e) Declaratives. The utterances attempt to change the world by representing it as having been changed, for example naming, sentencing, appointing, etc.

Directive, as one of linguistic features and a type of speech acts, constitutes expression to get another person to do something in particular. Directive speech act shows a relationship between speaker and hearer in which the speaker intends to make someone do something (Muhartoyo \& Kristani, 2013, p. 952). Flor and Juan (2010) as cited in Muhartoyo and Kristani (2013) mention that directive contains a verb, an object and a requested task performed by the speaker and the hearer.

As one of linguistic features, directive constitutes the expression in which one person tries to get another person to do something. Mulac et al. (2001, p. 147) point out that this lexical device can be expressed either in positive or interrogative sentence, for example, "write that down", "think of another", "why don't you put that down?"

In different field, the notion of directive is also discussed in speech act theory (Austin, 1962; Searle, 1969). In this case, directive shows a relationship between speaker and hearer in which the speaker intends to make someone do something, namely "makes the world fit words". Or to put it simply, "the speaker wants the situation" (Muhartoyo \& Kristani, 2013, p. 952).

Ervin-Tripp (1976, p. 29) suggests six kinds of directives that applicable to both spoken and written English according to the relative power of speaker and addressee in the usage and the obviousness of the directive. They are (1) Need statements, for example I need a match, (2) Imperatives, for example Give me a match and elliptical forms like $a$ match, (3) Imbedded imperatives, for example Could you give me a match?(4) Permission directive, for example May I have a match? (5) Question directives, for example Going to get a match? (6) Hints, for example The matches are all gone.

Studies of directive have been conducted in linguistic and literature fields. Amanda and Marlina (2018) analyze directive speech acts used in Frozen movie transcript. They categorized the directive speech act by using Levinson's theory: Asking, requesting, suggesting and stating. Suryanovika and Julhijah (2018) identified the category of directive speech acts found in utterances of six female characters of six Jane Austin's novels (Elinor Dashwood of Sense and Sensibility, Elizabeth Benner of Pride and Prejudice, Fanny Price of Mansfield Park, Emma Woodhouse of Emma, Anne Elliot of Persuasion, and Catherine Morland of Northanger Abbey). The findings show that directive speech acts are formed imperatively, declaratively, and interrogatively. Meanwhile, Winarti, et al (2015) discuss the directive speech acts contained in tembang dolanan by using a pragmatic approach. In the dolanan song, directive speech acts can be expressed directly or indirectly. Direct expression is conventionally used to rule, invite, and forward, while indirect expression is used when instead of by a command line, the intention is ruled by statement sentences, obligation-stating sentences, and questions.

Wulandarti (2017) writes that communicating among people will naturally require them to identify or recognize where they stand and how they behave with regard to their position. It has close relation with the social class where they belong. According to Chamber (2003) social classes is related to the social division in industrialized nations categorizing those who earn money by working with their hands and those earn money by pencil-work series (specifically the well-known divisions are between blue and white-collar). Labov (2006, p. 138) categorizes several social classes as follow :

Table 1. Labov (2006)'s social classess

\begin{tabular}{lll}
\hline \multicolumn{1}{c}{$\begin{array}{c}\text { Class } \\
\text { Title }\end{array}$} & \multicolumn{1}{c}{$\begin{array}{c}\text { Educational } \\
\text { Characteristics }\end{array}$} & $\begin{array}{l}\text { Occupational } \\
\text { Characteristics }\end{array}$ \\
\hline $\begin{array}{l}\text { Upper } \\
\text { Class }\end{array}$ & $\begin{array}{l}\text { College graduate } \\
\text { of the right } \\
\text { school }\end{array}$ & $\begin{array}{l}\text { First-rate } \\
\text { professional } \\
\text { manager, official, } \\
\text { or proprietor of } \\
\text { large business. }\end{array}$ \\
\hline $\begin{array}{l}\text { Upper } \\
\text { middle } \\
\text { class }\end{array}$ & College graduate & $\begin{array}{l}\text { Career men in } \\
\text { professions, } \\
\text { managerial, } \\
\text { official, or large } \\
\text { business position. }\end{array}$ \\
\hline $\begin{array}{l}\text { Lower } \\
\text { middle } \\
\text { class }\end{array}$ & $\begin{array}{l}\text { High school } \\
\text { graduate, } \\
\text { frequently with } \\
\text { specialized } \\
\text { thereafter }\end{array}$ & $\begin{array}{l}\text { Semiprofessional, } \\
\text { petty businessman, } \\
\text { white collar } \\
\text { foreman and } \\
\text { craftsman. }\end{array}$ \\
\hline $\begin{array}{l}\text { Working } \\
\text { class }\end{array}$ & $\begin{array}{l}\text { Some high } \\
\text { school }\end{array}$ & $\begin{array}{l}\text { Operative: blue } \\
\text { collar workers at } \\
\text { the mercy of the } \\
\text { labor market. }\end{array}$ \\
\hline
\end{tabular}




\begin{tabular}{lll}
\hline $\begin{array}{l}\text { Lower } \\
\text { class }\end{array}$ & Grade school or & Laborers: last to be \\
& less & $\begin{array}{l}\text { hired and first to } \\
\text { be fired, frequent } \\
\end{array}$ \\
& job shifts.
\end{tabular}

This paper took two social classes: upper class and lower class which are related to the educational and occupational background of the characters narrated in the novels. According to Wulandari (2017:46) novel is closely related to humans' experience, in which it is usually portrayed through a series of experiences. Furthermore, Wulandari (2017:46) argues that analyzing novel might also reveal the essence of human's life in their language. A novel can be defined as an invented prose of narrative which constitutes a relatively long written work and a certain complexity that deals imaginatively with human experience, usually through a connected sequence of events involving a group of persons in a specific setting (Burges, 2016). Based on the explanation previously, this study analyzes the use of directive speech act in the utterances from two different novels which portrayed upper and lower class society.

\section{RESEARCH METHODOLOGY}

This study applies text analysis method as McKee (2001:138) considers that textual analysis is a way for researchers to gather information about how human beings make sense of the world. It is a methodology which constitutes a data- gathering process for those who want to understand the ways in which members of various cultures and subcultures make sense of who they are and of how the fit into the world in which they live. Frey, et al (1999) wrote that the notion of text contains written words that can be found in books, novels, magazines, movie transcript, advertisements, graffiti and many more. Since the data of this study is qualitative data, therefore this study also employ qualitative method as Frankel and Wallen (2006) point out that since it is related to natural inquiry thus qualitative is closely related to the following characteristics, such as emphasizing the nature rather than experiment, considering more on process rather than the product, emphasizing more don description instead of fix calculation.

The source of data was taken from the utterances of the main character of two novels: Crazy Rich Asians and I am The Messenger.

\section{Crazy Rich Asian}

The Goodreads website wrote that it is the outrageously funny novel about three super-rich, pedigreed Chinese families and the gossip, backbiting, and scheming that occurs when the heir to one of the most massive fortunes in Asia brings home his American born Chinese girlfriend to the wedding of the season. The main character portrayed in this novel namely Nicholas Young, the heir of an extremely wealthy Singaporean family. The conflict involve an American-Chinese born who's been rejected by Nick's crazy rich families. When Rachel Chu agrees to go to Singapore with Nick, her handsome boyfriend, she envisions a humble family home, long drives to explore the island, and quality time with the man she might one day marry. She is excited to meet Nick's friends and family. What she doesn't know is that Nick's family home happens to look like a palace, that she'll ride in more private planes than cars, and that with one of Asia's most eligible bachelors on her arm, Rachel might as well have a target on her back. Nick fails to warn her about the social minefield she's about to cross. Beyond her imagination, Rachel meets Astrid, the It Girl of Singapore society; Eddie, whose family practically lives in the pages of the Hong Kong socialite magazines; and Eleanor, Nick's formidable mother, a woman who has very strong feelings about who her son should - and should not - marry because of one reason that Rachel comes from different class. Eleanor, jets off to Shenzhen to investigate Rachel's background, while friends and family gossip openly about her at a gathering hosted by Nick's grandmother. When Rachel is invited to the bride's bachelorette party which includes a ride on a private jet and a stay at a luxury hotel it becomes clear that there are young women that are instructed by Nick's mother to do just about anything to scare Rachel off. His mother and grandmother disagree seriously if Nick marries Rachel.

\section{I am The Messenger}

I am The Messenger written by Markus Zusak published in 2006. Referring to The Goodreads, I am The Messenger tells about a man namely Ed Kennedy who is an underage cabdriver without much of a future. He is pathetic at playing cards, hopelessly in love with his best friend, Audrey, and utterly devoted to his coffee-drinking dog. His life is peaceful until he inadvertently stops a bank robbery. It is started from a bank robbery which happened when Ed visited the bank with his friends. Ed was successful to foil the robbery when the robber tried to escape with his friend's car parked near the bank. 
After speaking to tell the chronology to the police, Ed became famous person. He was interviewed by local media and he was proclaimed a hero. The life of Ed had change from zero to hero. Many people knew about his heroic action. Ed usually met his friends to play cards every week. They were Ritchie, who was unemployed; Marv was a stingy carpenter who owned the car, and Audrey, a fellow cab driver who Ed was in love with. Unfortunately she didn't have the feeling like he did. Ed had a bad relationship with his mother due to the fact that $\mathrm{Ed}$ was as same as his late father. His mom hated his father. His poor father had just passed away recently.

There were several steps taken to collect the data. First the write read the novels carefully, focuses on the utterance of the main character Nicholas Young and Ed Kennedy o seek the directives speech act. Then all of Nicholas Young and Ed Kennedy's directive utterances were classified based on the types of directive proposed by Ervin-Tripp (1976). Finally, in-depth analysis was conducted to assure how the data were portrayed in the novel.

\section{FINDING AND RESULT}

Table 2 below shows the result of the classification of directive utterances based on the types of directive proposed by Ervin-Tripp (1976).

Table 2. Types of directive utterances in two novels

Types of directive (Ervin-Tripp, 1976)

Directive utterances

\section{Upper class $\quad$ Lower class}

\begin{tabular}{lllll}
\hline Need statement & 4 & $8 \%$ & 8 & $16 \%$ \\
Imperatives & 42 & $80 \%$ & 42 & $82 \%$ \\
Imbedded imperative & 1 & $2 \%$ & 1 & $2 \%$ \\
Permission directive & - & - & - & - \\
Question directive & 4 & $8 \%$ & - & - \\
Hint Total & 1 & $2 \%$ & - & - \\
$\quad 52$ & $100 \%$ & 51 & $100 \%$ \\
\hline
\end{tabular}

From the table 2, we can see that there are 52 directive utterances of Nicholas Young found in the novel Crazy Rich Asians as the representative of the upper class society and there are 51 directive utterances of Ed Kennedy in the novel I am the Messenger as the representative of the lower class society.

The first types of directive proposed by Ervin-Tripp (1976) is 'need statement' directive. There are 4 or $8 \%$ utterances of Nicholas Young that can be categorized in 'need statement' directive. The examples of those utterances are:

"Ah, Ma, I'd like you to meet my friend Rachel Chu, from America." (Chapter 2 page 177)

"I need you to stop this boat, and I need our precise coordinates right now." (Chapter 15 page 292)

Meanwhile, there are 8 or $8 \%$ utterances of $\mathrm{Ed}$ Kennedy that can be categorized in 'need statement' directive. The examples of the utterances from $\mathrm{Ed}$ Kennedy are:
"I want to hear you say it." (Chapter 13 page 87 )

“I need your help, Bernie.” (Chapter 4 page 277)

According to Ervin-Tripp (1976:193) need statement occurred in transactional work setting and in family setting where the statements of need were directed from persons of higher rank to persons of lower rank or were spoken to persons whose transactional role obligated compliance.

The second type of directive is 'imperative' directive. There are $42(80 \%)$ utterances of upper class novel character that can be classified into 'imperative' directive. The excerpts are:

"Come in, let me show you where I grew up." (Chapter 1 page 15).

"Don't worry, once we arrive everything will get sorted." (Chapter 4 page 35). 
Meanwhile, there are $42(82 \%)$ utterances of lower class novel that can be classified in 'imperative' directive. The excerpts are:

\section{“Get your foot off me." (Chapter 1 page 7) \\ “Just pay up.” (Chapter 12 page 75)}

Based on Ervin-Tripp (1976:128) imperatives are certainly the most obvious directive and there is no way to make them ambiguous in function. In other words, imperative directive is an absolutely necessary of a request or an order given by the speaker to the hearer.

The third type of directive is 'imbedded imperatives'. There is one $(2 \%)$ of utterance from both the upper and lower classes characters. These are the utterances of imbedded imperatives:

"Would you mind taking a taxi to my grandmother's?" (Crazy Rich Asians, chapter 18 page 154).

"Marv, could you stop with the key and be serious for a minute or two?" (I am the Messenger, chapter 7 page 303).

According to Ervin-Tripp (1976:129) “imbedded imperatives are those in which the requested act is preceded by an introductory phrase, such as "can you ...", "would you mind...", "would you..." It is interpreted as a command to do if it fulfills all the following conditions: (i) it contains one of the modals, can, could, will, would; (ii) the subject of the clause is also addressee; (iii) the predicate describes an action which is physically possible at the time of utterance.

The fourth type is permission directive which is not found in both main characters from upper class and lower class. According to Ervin-Tripp (1976) permission directives are statements that appear to ask permission but that require action of the part of the addressee. These appear to operate like embedded imperatives, but there is a shift in focus.

The fifth type is question directive. This type was found in the utterances from upper class (4 utterances or $8 \%$ ) and was not found in the utterances from lower class. These are the four utterances of question directive spoken by Nicholas Young in Crazy Rich Asians novel.

“Rachel, why don't you get started?" (chapter 2 page 181)

"Why don't you call her and talk it over?" (chapter 6 page 218)
"I have an idea- why don't we go away tomorrow?" (chapter 10 page 431)

"Why don't we get off this mountain and spend the night in K.L?" (chapter 13 page 469)

Ervin-Tripp (1976:132) explains that, "Question directives are interpreted the questions literally and infer that a question about the presence of the subject could only be based on a desire to speak to. The usual way to realize a question directive is through an information question. The question directive represents a form that potentially neutralizes the contrast between directives and information seeking-it is a pragmatic neutralization".

The last type is namely 'hint'. The writer found only one utterances $(2 \%)$ of hint directive in the character of upper class and did not find any of hint directive utterances in the character of lower class.

"Hey, don't forget to breath." ( chapter 18, p. 315).

Sinclair and Coulthard (1974, p.32) as cited in Ervin-Tripp (1976, p. 138) stated that hints directive are used in situation where there are rules or common agreements about prohibited acts, mere mention of a prohibited act or an unmet obligation functions to frame a command.

\section{CONCLUSION}

The use of directive speech act in the main character of two novels Crazy Rich Asians and I am The Messenger which are the representative of two different social class, upper and lower class could be considered as a portrayed of a real life since fiction works reveal the essence of human's life in their language. The finding of this study showed that the majority type of directive in the main characters of two novels in both of social classes is imperative directive, followed by need statement, question directive, imbedded imperative and hint. There is a slightly differences of the use of directive between upper and lower class society. In upper class, the character represented happiness, power of money, richness and everything related to the wealth. Generally, upper class people use the directive as commands to their employees. Meanwhile, in lower class, the character narrated as people who were not educated well, poor, and frustrated in work, love and life. The lower class character used directive in his work as a cab driver which required him to be more direct in asking and offering the customers.

\section{REFERENCES}


Austin, J. L. (1962). How to do things with words. Oxford: Oxford University Press.

Amanda, V., \& Marlina, L. (2018). Directive speech acts used in Frozen movie transcript. EJournal of English Language \& Literature $7(1), 218-224$

Burges, A. (2006). Novel. Retreived from Encyclopedia of Britannica: https://www.britannica.com/art/novel.

Chamber, J. (2003). Sociolinguistic theory: Linguistic variation and its social signigicance. Oxford: Blackwell Publisher.

Corbett, G. G. (2006). Linguistic features. In Keith Brown (Ed.), Encyclopedia of Language and Linguistics, ( $2^{\text {nd }}$ ed., pp. 193-194). Oxford: Elsevier

Ervin-Tripp, s. (1976). "Is Sybill there? The structure of some American English directives". Language in Society, 5(1), 2566.

Frey, L., Botan, C., \& Kreps, G. (1999). Investigating communication: An introduction to research methods $\left(2^{\text {nd }} e d\right.$. $)$. Boston: Allyn \& Bacon.

Frankel, J. R., \& Wallen, N.E. (2006). How to design and evaluate research in education in education $\left(5^{\text {th }}\right.$ ed.). New York: McGrawHill Publishing.

Kwan, K. (2014). Crazy rich Asians. New York: First Anchor Books

Labov, W. (2006). The social stratification of English in New York City. (2 $\left.{ }^{\text {nd }}.\right)$. Cambridge: Cambridge University Press.

Lee, K.B. (2006). A study of linguistic features in Hong Kong Chinese Newspaper Headline (Master's thesis). University of Hong Kong, Pokfulam, Hong Kong.

Leech, G. (1996). Principles of pragmatics. London : Longman.

Matiini, G. (2015). A factorial analysis of linguistic features patterns used in English speaking country and non-English speaking country thesis writings (Master's thesis). Atma Jaya Catholic University of Indonesia, Jakarta, Indonesia.

Mulac, A., Giles, H., Bradac, J. J., Palomares, N. A. (2013). The gender-linked language effect:
An empirical test of a general process mode. Language Sciences, 38, 22-31.

Muhartoyo \& Kristani, K. (2013). Directive Speech Act in the movie 'Sleeping Beauty'. Humaniora 4(2), 949-966.

McKee, A. (2001). A beginner's guide to textual analysis. Metro Magazine, Pp. 138-149

Suryanovika, C., \& Julhijah, N. (2018). Directive speech acts and hedges presented by female main characters of Jane Austen's novels. Lingua Cultura, 12(4), 345-350.

Searle, J. C. (1969). Speech acts: An essay in the philosophy of language.Cambridge: CUP

Winarti, D., Wijana, I. D. P., Poedjosoedarmo, S., Ahimsa-Putra, H. S. (2015). Variations of directive speech act in TEMBANG DOLANAN. Humaniora, 27(3), 305-316.

Wulandari, A. D. (2017). Linguistic features used by male and female characters in different social classes: A study of politeness strategy and directive speech act. (Master's Thesis). Atma Jaya Catholic University of Indonesia, Jakarta, Indonesia

\section{WRITER'S PROFILE}

Dwi Indarti, M. Hum joined in Bina Sarana Informatika University, majoring in English department since 2015. She graduated from undergraduate school of STIBA Nusa Mandiri, majoring English Letters and graduate school of Catholic University of Atma Jaya Jakarta, majoring in Applied English Linguistic. She has published and presented several papers in some journals, national and international conference and seminars, such as: Lexical richness of The Jakarta Post opinion articles: Comparison between native and non-native writers, Patterns of rhetorical organization in The Jakarta Post opinion articles, Language and gender in teen short-stories, Syntactic complexity of online newspaper editorials across countries, Politeness strategy of directive speech acts in Betawinese short-stories SEBELAS COLEN DI MALAM LEBARAN SETANGKLE CERITA BETAWI, Analysis of Betawi Language from Linguistic feature perspective: A case study of Portalbetawi.com, Sequential organization of Indonesia stand-up comedy performance, Lexical richness of students' writings, Analyzing critical thinking in reading comprehension section of TOEFL book 